\title{
PETER FORSSKÅLS BIDRAG TIL ARABISK LEKSIKOGRAFI
}

\author{
AF
}

PHILIPPE PROVENÇAL

$\mathrm{D}^{\circ}$ er er ingen del af den klassiske islamiske videnskabshistorie, som er mindre undersøgt end den, som relaterer sig til naturhistorie og biologi. Hvad dette angår, så er teksterne, også de vigtige tekster, stort set alle sammen ubehandlede. Der er en del årsager til denne tingenes triste tilstand. For det første har langt de fleste arabister og semitiske filologer ingen faglig baggrund indenfor biologien. Dernæst er selve den sproglige behandling af det klassiske arabiske biologiske vokabular stadigvaek særdeles mangelfuld. For at sige det direkte står langt de fleste dyre- og plantenavne, som man traffer i de klassiske arabiske tekster, og som ikke står for husdyr, kendte nytteplanter eller særdeles kendte vilde arter, med en ukendt artsidentitet. På denne baggrund er det forståeligt, at botaniske og zoologiske tekster forbliver særdeles uigennemsigtige. At mange naturhistoriske tekster oven i købet tilhører den genre indenfor arabisk litteratur, nemlig adab, som rettelig kan betegnes som begavet men populær dannelseslitteratur og derfor i deres redigering og indhold retter sig efter deres målgruppe, som er den brede men dannede del af befolkningen, gør, at deres indhold oftest systematiseres efter alt andet end moderne naturhistoriske kriterier. Det naturvidenskabelige indhold bliver derved uigennemsigtigt for den person, som ikke er skolet i de biologiske fag.

Behandlingen af de arabiske artsnavne kan følge to metoder, som i høj grad supplerer hinanden. Dels kan man prøve på at identificere arten på de beskrivelser, som teksterne giver, og dels kan man rejse i de arabisksprogede lande og interviewe lokalbefolkningen om de lokale arabiske artsnavne. Ved en kombination af begge metoder er det så mange gange muligt at pejle sig ind på en artsidentifikation. Jeg har brugt begge metoder i mit videnskabelige arbejde, og mine egne erfaringer på dette område viser, at man kan opnå resultater, som stræk- 
ker sig fra den helt sikre identifikation til den noget teoretiske, men dog samtidig godt sandsynliggjorte identifikation.'

Det siger sig selv, at jo flere kilder man har til sin rådighed, jo bedre står man stillet i sit identifikationsarbejde. Den ultimativt bedste kilde er i så henseende en person, som både er uddannet biolog og semitisk filolog. Denne fagkombination er i sandhed sjælden, men det er faktisk den vi finder hos Peter Forsskål, som var uddannet i semitisk filologi hos professor Johann David Michaëlis (1717-1791) og uddannet i zoologi og botanik hos Carl von Linné (1707-1778).

\section{Forsskills liv og kamiere}

Forsskål blev født i 1732 i Helsingfors. Han flyttede med sin fader i $174^{1}$ til Tegelsmora i Uppland, idet faderen fik et præstekald på dette sted. Han blev allerede som 1o-årig tilmeldt universitetet i Uppsala som studerende, og fik sin afsluttende eksamen i $175^{1}$. Fra $175^{1}$ til ${ }^{175^{6}}$ læste han filosofi, orientalske sprog, zoologi og botanik både i Uppsala, hvor han havde den da verdensberømte Linné som lærer, og i Göttingen i Tyskland, hvor han havde en af datidens førende orientalister, professor Michaëlis, som lærer. Han fortsatte med at studere alle disse fag efter sin hjemkomst til Sverige i $175^{6}$, medens han tjente som huslærer hos en greve.

I 1759 lagde Forsskål sig ud med ud med den politiske elite i Sverige ved på svensk at trykke et skrift om borgerlig frihed. ${ }^{2}$ I mellemtiden var han blevet foreslået som naturforsker på den danske videnskabelige ekspedition til Arabien af Michaëlis. Linné rådede Forsskål til at sige ja, og på den måde blev han ekspeditionsmedlem i den af Kong Frederik 5. udsendte videnskabelige ekspedition til Egypten og Jemen.

Forsskål forberedte sig med ildhu fagligt til rejsen, og på selve rejsen udviste han en imponerende flid og dygtighed. I Jemen blev han ramt

\footnotetext{
${ }^{1} \mathrm{Ph}$. Provençal Enquête lexicographique sur les noms d'animaux en arabe / A lexicographic survey of arabic animal names. Ph.D.-afhandling ved Carsten Niebuhr Instituttet for Nærorientalske Studier, Københavns Universitet 1995. 2. udg. 1996; og Ph. Provençal, Animal names gathered by interviews with members of the Muzin tribe in Sinai, Acta Orientalia LVIII, 1997 , s. 35-46.

${ }^{2}$ Tankar om borgerliga friheten, Uppsala 1759 .
} 


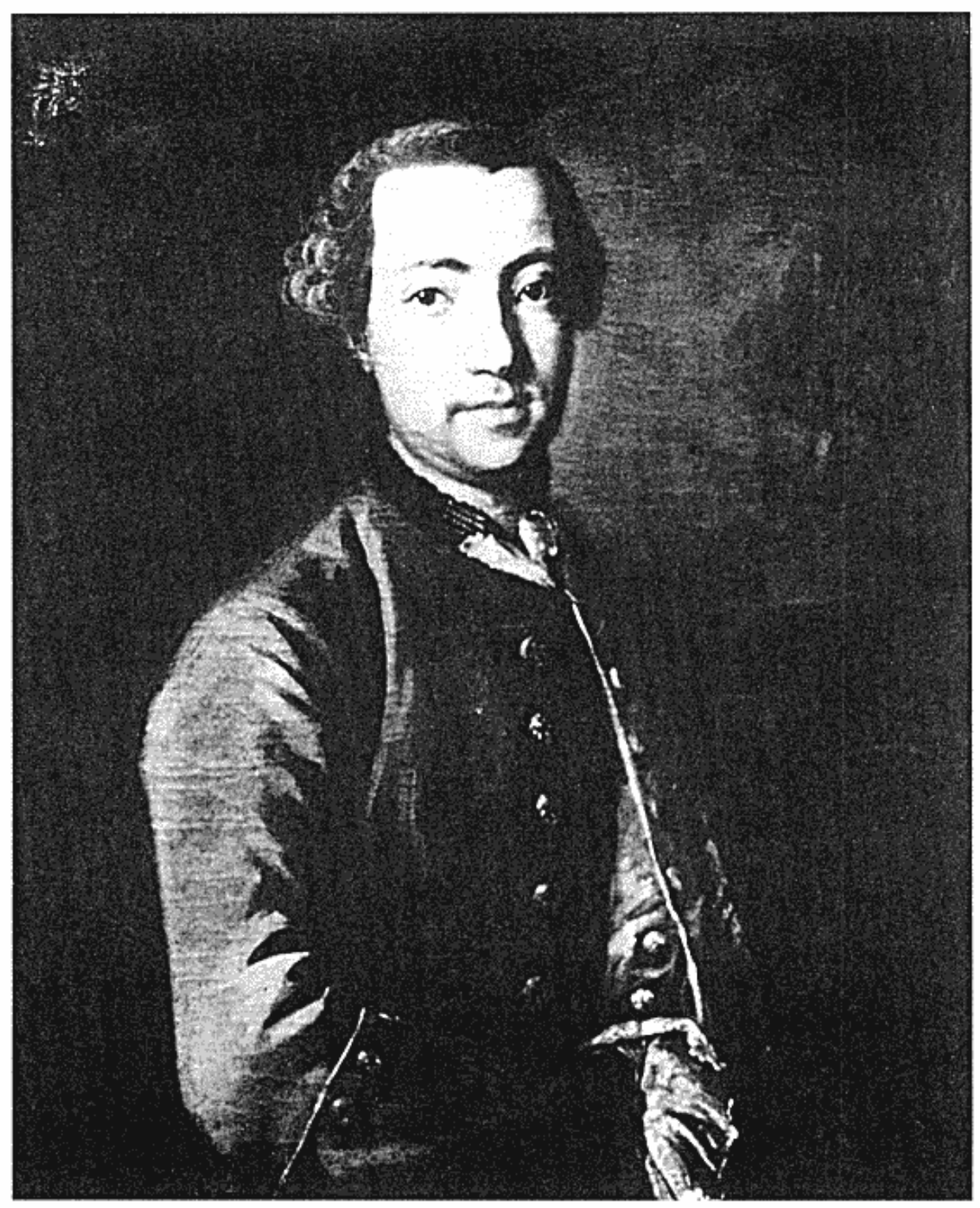

Peter Forsskål $\left(173^{2-1} 7_{63}\right)$. Portratmaleri af P. Dahlman 1760 . Salnecke Slott, Uppland. 
af malaria ligesom de øvrige ekspeditionsdeltagere og døde i Jerîm på vej til San'â den 11 . juli $1763 .^{3}$

\section{Forsskåls betydning for arabisk leksikografi}

I oplysningstiden bliver rationalismen ledemotivet både i videnskaben og filosofien. Det betyder, at selv Bibelen kan gøres til genstand for rationel videnskabelig forskning. En af de store forhindringer var imidlertid, at det hebraiske sprog i Det Gamle Testamente står ret alene blandt de semitiske sprog. Det sprog, som Det Gamle Testamente står skrevet på, findes faktisk kun i Det Gamle Testamente, samt på potteskår, såkaldte ostraka, og i Shiloâ-indskriften i Jerusalem. Disse epigrafiske kilder var ikke kendte i 17 oo-tallet," ejheller de vasentlige fund indenfor akkadisk, ugaritisk og andre semitiske oldsprog, som først er blevet gjort i løbet af $1800-$ og 19oo-tallet. Hele den nærorientalske arkæologi var ikke startet endnu, og Den Arabiske Rejse repræsenterer et af de første forsøg på at arbejde videnskabeligt med mellemøstlige spor fra oldtiden. Ekspeditionens initiativtager, J.D. Michaëlis i Göttingen, skriver i sit forslag til en ekspedition til Jemen, dengang også kaldet for Arabia Felix efter romersk skik: "Dette lands natur er stadigvak rig på gaver, som er os ubekendte...Dets dialekt er endnu forskelligt fra det os bekendte vestlige arabisk, og eftersom denne form for arabisk, som er den vi kender, hidtil har været det sikreste hjælpemiddel til forklaring af det hebræiske sprog, hvilket lys må vi da ikke med rimelighed forvente, at der bliver kastet over Bibelen....dersom vi lærte Arabiens østlige dialekt at kende lige så godt som den vestlige ". ${ }^{6}$

I den kongelige instruks af 15 . december 176 o pålægges det i $\$ 18$ udtrykkeligt Forsskål, at alle naturalier, som han nævner i sine optegnelser, skal forsynes med arabiske navne, og at disse skal noteres både

\footnotetext{
${ }^{3}$ Alle oplysninger om Forsskåls liv er hentet hos Torben Wolff og Stig T. Rasmussen i Den Arabiske Rejse ${ }_{1} 7_{1-1} 7^{67}$, en dansk ekspedition set i videnskabshistorisk perspektiv, red. Stig T. Rasmussen, 1990.

${ }^{4} \mathrm{~J}$. Pedersen Hebraisk Grammatik, 1981.

${ }^{5}$ Navnet for landet Jemen kommer fra det arabiske Bilâd al-Yaman, som direkte oversat betyder: Det Sydlige Land, eller kort og godt Sydarabien. Imidlertid er ordet for syd på arabisk sammenfaldende med ordet for højre - det sidste dog oftest udtalt yamin. Romerne har så misfortolket begrebet højre for lykkelig, i modsatning til venstre sinistrum, som stăr for det uheldssvangre.

${ }^{6}$ Rasmussen (note 3 ) s. $10-11$.
} 
med arabiske og latinske bogstaver. ${ }^{7}$ At Forsskål omhyggeligt fulgte instruksen kan ses af, at der allerede er optegnet $7^{\circ}$ arabiske dyrenavne på de første fire sider af Conspectus i Descriptiones Animalium. ${ }^{8}$ Dette navnemateriale er ikke tidligere blevet gjort til genstand for videnskabelige studier.

Forsskåls betydning for den leksikografiske behandling af arabiske dyrenavne er, at hans identifikation af den biologiske art er videnskabeligt sikker: Forsskåls beskrivelser er stadig gældende som videnskabeligt definerende beskrivelser af mange dyr og planter, og dermed følger, at de videnskabelige navne, som han gav dyrene og planterne efter det linnéiske sytem, stadigvæk er gældende for mange arters vedkommende. ${ }^{9}$ Det vil sige, at man kan være sikker på, at det arabiske artsnavn lymma, ${ }^{10}$ som er noteret af Forsskål for den blåplettede pilrokke, rent faktisk står for den blåplettede pilrokke: Taeniura lymma." Denne naturvidenskabelige sikkerhed giver en fast basis for at arbejde videre med det arabiske materiale.

Arabisk findes i to forskellige udgaver. Dels det klassiske sprog, som har været det officielle sprog siden de ældste tider, dels de mange lokale dialekter. Ordforrådet mellem dialekterne og klassiske arabisk er for en stor del fælles. Man kan med held sammenligne forholdet med forskellene og lighederne mellem norsk, svensk og dansk. Når det gaelder dyrenavne, plejer man at definere klassiske arabiske dyrenavne som de navne, man finder $\mathrm{i}$ de tekster, som står skrevet på klassisk arabisk. Overgangen mellem klassisk og dialekt er selvsagt ikke entydig, og mange klassiske tekster udviser dialektismer. Klassisk arabisk er efter alt at dømme et digterisk højsprog, som blev brugt som

\footnotetext{
${ }^{7}$ Rasmussen (note 3) s. 7o.

${ }^{8}$ Der er 72 navne, hvis vi tager navnene tahîsh og nebâsh med; det er imidlertid navne på et sagndyr (animal fabulare), som Forsskål tog med for fuldstæendighedens skyld.

9 Alene blandt fiskene findes på Zoologisk Museum, Københavns Universitet, stadigvak $5^{8}$ typeeksemplarer, det vil sige de eksemplarer, hvis beskrivelser har dannet grundlag for den biologiske navngivning af den pågaldende art (Klausewitz og Nielsen „On Forsskall's collection of fishes in the Zoological Museum of Copenhagen“, Spolia Zoologica Musei Hauniensis XXII, $19^{6}$, s. 9 ).

${ }^{10}$ Det er lidt underligt at et arabisk ord transkriberes med et y, men hvis man holder sig til den måde ordet blev stavet på med arabiske bogstaver, således som den stån $\mathrm{i}$ Descriptiones Animalium, blev navnet efter al sandsynlighed udtalt limmâ.

${ }^{11}$ P. Forskâl Descriptiones Animalium, post mortem auctoris edidit Carsten Niebuhr, 1775 .
} 


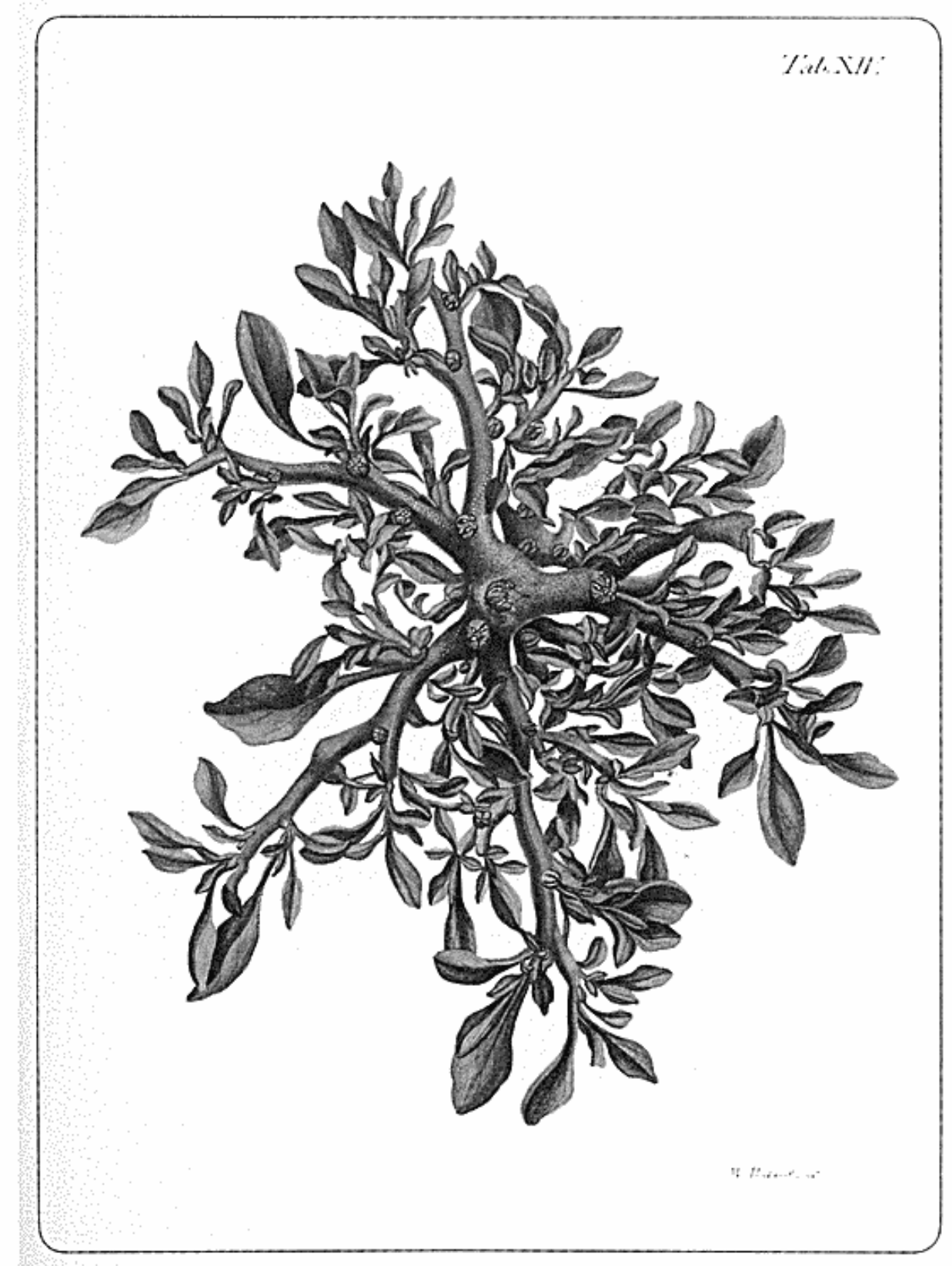

Icones rerum naturalium, 1776 , planche 14 .

Denne plante Aizoon canariense hedder ifø̆lge Forsskål Kusjet el Bellâd eller med moderne transskription: kushat al-bilâd. Det er en af de planter, som har skiftet videnskabeligt navn, siden Forsskål beskrev den, idet Forsskål gav den navnet Glinus chrystallinus. Dens navn skulle måske laeses kushshat al-bilâd med fordoblet midterste konsonant i det første ord. Navnet skulle da betyde „landets (eller jordens) pandelok“, hvilket kunne passe med plantens udseende. Dette er et af de plantenavne, som Forsskål skrev med både latinske og arabiske bogstaver. Tegningen er udført af G.W. Baurenfeind, som var den tegner, som af regeringen $\mathrm{i}$ København var blevet sendt med ekspeditionen som dens illustrator, på samme måde som en professionel fotograf kan rejse med moderne ekspeditioner. Hans opgave var blandt andet at bista ekspeditionen med at tegne og illustrere de naturalier, som man ikke kendte i Europa. 
fællessprog af de forskellige arabisktalende stammer i 5 oo-6oo tallet. Koranen blev skrevet ned på dette højsprog, og det blev kodificeret af arabiske grammatikere i de irakiske byer Basra og Kûfa i løbet af 7oo-tallet. Dette højsprog er efter al sandsynlighed nogenlunde lig med talesproget hos de store central- og østarabiske stammer i $5^{\text {oo- }}$ 600 tallet. ${ }^{12}$

Problemet vedrørende dyre- og plantenavne på arabisk er ikke kun, at man ofte står med en ukendt artsidentitet, men at navnenes etymologier, det vil sige deres oprindelser og udviklingshistorier, er så indviklede og forskelligartede. Da de arabiske stammer fik erobret det islamiske rige, mødte de i de nyerobrede områder en flora og en fauna, som de ikke kendte hjemmefra, og som de kun kunne betegne med artsnavne stammende fra det lokale sprog. Som eksempel kan navnes nilkrokodillen Crocodylus niloticus. Der er ingen krokodiller på den arabiske halvø, og ej heller i Mesopotamien. Da de islamiske tropper erobrede Egypten, kunne de arabisktalende beduinkrigere kun betegne nilkrokodillen med det lokale ægyptiske ord, det vil sige det koptiske ord emsahh. Ordet er hunkøn på koptisk, og da den bestemte artikel i hunkøn på koptisk er et „t“ eller et „ti“, bevirker det, at krokodille på arabisk kom til at hedde timsâh. På arabisk determineres det imidlertid med den arabiske bestemte artikel „al“, hvorved vi får, at „krokodillen" kommer til at hedde al-timsâh, og det er ydermere blevet til et hankønsord.

Ud over, at mange artsnavne stammer fra det lokale sprog, er der en del artsnavne, som stammer fra græsk, enten hentet direkte fra det byzantinske talegræsk eller ført ind i det arabiske sprog som følge af den store og for videnskabernes historie særdeles betydningsfulde oversæettelsesaktivitet, som blev udført i det 9 . århundrede for at oversætte videnskabelig litteratur fra især græsk til arabisk. Selv om mange af oversætterne var dygtige filologer, skete det alligevel tit, at mange artsnavne simpelthen blev overtaget fra græsk, også selv om der rent faktisk fandtes arabiske navne for de pågxldende dyr og planter, således at for eksempel det graske ord for trane "géranos“ blev til ghirnawq, ghumayq, ghurnûq eller til andre variationer over dette tema. I de ældre arabiske zoologiske tekster sidestilles det med det arabiske ord for trane kurkî, men senere synes de to ord at have stabiliseret sig betydningsmæessigt, således at kurkî er blevet til artsbetegnelsen for

${ }^{12} \mathrm{Cr}$. R. Blachère Histoire de la litterature arabe, Paris $1980, \mathrm{~s} .79^{-81}$. 
tranen Grus grus, medens ghimawq osv. er blevet til artsbetegnelsen for jomfrutranen Anthropoides virgo. ${ }^{13}$

I overensstemmelse med instruksens punkt 18 noterede Forsskål de dialektale navne ned. Dette betyder ingenlunde, at Forsskåls indsamlede materiale ingen betydning har for forståelsen af de klassiske tekster; tvartimod, da mange og måske ligefrem de fleste dyrenavne på klassisk arabisk stammer fra de dialektale navne, ${ }^{1.4} \mathrm{og}$ da en fælles enighed om brugen af dyrenavne på klassisk arabisk først for alvor begyndte at gøre sig gældende i det 10.-11. århundrede, er Forsskåls samlinger en særdeles vigtig kilde til forståelse af dynamikken i hele denne proces, også selv om de blev indsamlet og noteret 700 år efter, at konsensus vedrørende klassiske arabiske dyrenavne var opnået. Da mange af navnene desuden er forblevet uforandrede siden de aldste tider ${ }^{15}$ giver Forsskåls samlinger derfor næsten uvurderlige bidrag til arbejdet med denne specielle del af den arabiske leksikografi og videnskabshistorie.

\section{Forsskåls arabiske fortegnelser}

Da Carsten Niebuhr kom hjem den 20. november 1767 , var interessen for den danske ekspedition til Egypten og Jemen nedtonet, således at det var Carsten Niebuhr, der for egen regning måtte tage sig af at sammenfatte og publicere Forsskåls optegnelser. Der blev to værker, og begge blev udgivet i 1775 og trykt på Möllers bogtrykkeri i København: et botanisk med titelen: Flora Agyptiaco-Arabica sive descriptiones plantarum quas per Kgyptum Inferiorem et Arabiam felicem detexit, illustravit Petrus Forskål, [Ægyptisk-arabisk flora, eller plantebeskrivelser som Peter Forsskål har fuldført i Nedre Egypten og i Det Lykkelige Arabien og

${ }^{13}$ Cf. Ph. Provençal og U. G. Sørensen „Medieval Record of Siberian White Crane Grus leucogeranus in Egypt“, Ibis 1998, s. $333-335$.

${ }^{14}$ Det er kun dyr og planter, som findes pả den Arabiske Halvø og i de tilgransende havområder, som kan siges oprindeligt at have haft et navn på klassisk arabisk.

${ }^{15}$ Blandt fuglene alene kan navnes, at det klassiske arabiske ord for trane kuk $\hat{\imath}$ stadigvek er i brug som navn på denne fugl både på klassisk arabisk og $\mathrm{i}$ mange dialekter. Ligeså er klassiske navne som 'andalîb for nattergal og bulbul for de drossellignende fugle af Pycnonotus slagten stadigvak de officielle navne for disse arter. Det gamle falles semitiske ord for store svevende rovfugle nisr bruges stadigvak både på det klassiske sprog og på dialekter, cf. Provençal 1997 (note 1) s. 37 nr. 12 og s. 42. Mange flere eksempler på, at gamle navne holder sig, kunne anføres. 
forklaret]; og et zoologisk med titlen Descriptiones Animalium - Avium, amphiborum, insectorum, vermium qua in itinere orientali observavit Petrus Forskål [Beskrivelse af dyr - fugle, amfibier, insekter, orme ${ }^{16}$ som Peter Forskål har observeret under den orientalske rejse]. Begge værker indeholder arabiske navne på henholdsvis planter og dyr. I overensstemmelse med den kongelige instruks står navnene skrevet både med arabiske og med latinske bogstaver. Dog er det således, at en del navne står udelukkende på det ene eller det andet alfabet. Således er mange fuglenavne udelukkende skrevet med latinske bogstaver. Hos mange af fiskene står der to eller tre navne på det latinske alfabet, men kun et af dem står også på arabisk, eller også står det hyppigst anvendte navn på arabisk, medens andre navne kun står med latinske bogstaver. Lignende forhold gør sig gaeldende for plantenavnenes vedkommende, således at kun godt $2 / 3$ af plantenavnene står opgivet på begge alfabeter. ${ }^{17}$ Da Forsskål skrev de dialektale navne ned, følger disse ikke altid reglerne for klassisk arabisk, men Forsskål var en god filolog, og han kunne sagtens gennemskue, hvilke endelser og andre grammatikalske træk, der svarede til hinanden på de arabiske dialekter og på klassisk arabisk. Det tjener ham til ære, at han tilsyneladende ikke lod sig forlede til at gøre de dialektale dyre- og plantenavne mere klassiske i sin notation, men skrev tingene ned, således som han hørte dem. Som eksempel kan nævnes den arabiske fællesbetegnelse for muræner på Sinai og de arabiske kystområder ved Rødehavet. Disse hedder shâgga eller shogga på dialekt, men den klassiske skrivemåde ville i transskription være shâqqah eller shâqqat. ${ }^{18}$ Ikke desto mindre skriver Forsskål:

„1. MURÆNA guttata: .... Djiddæ. Arab. Sjacka. 2. MURÆNA tota cineræa. Arab. Sjoga vel Schoga [dernæst navnet med arabiske bogstaver], nomen commune toti huic generi“ [fæelles betegnelse for hele denne (fiske) slægt]. ${ }^{19}$

Når det galder Forsskåls transskriptioner til latinske bogstaver, kan de give anledning til tvivl om ordenes rette udtale. Dette skyldes dels, at de standardiserede transskriptionsmetoder, som vi bruger nu, slet

\footnotetext{
${ }^{16}$ Mange af de dyr, som Peter Forsskål grupperede under de næevnte betegnelser, grupperes helt anderledes efter den moderne systematik.

${ }^{17}$ G. Schweinfurth Arabische Pflanzennahmen aus Aegypten, Algerien und Jemen, Berlin 1912 , s. XVIII - XIX.

${ }^{18}$ Navnet kan oversettes til "flanseren" og hentyder til muranernes vane med at bide voldsomt fra sig med deres sylespidse tænder, når de fanges eller såres.

19 Descriptiones Animalium (note 11) s. 22.
} 


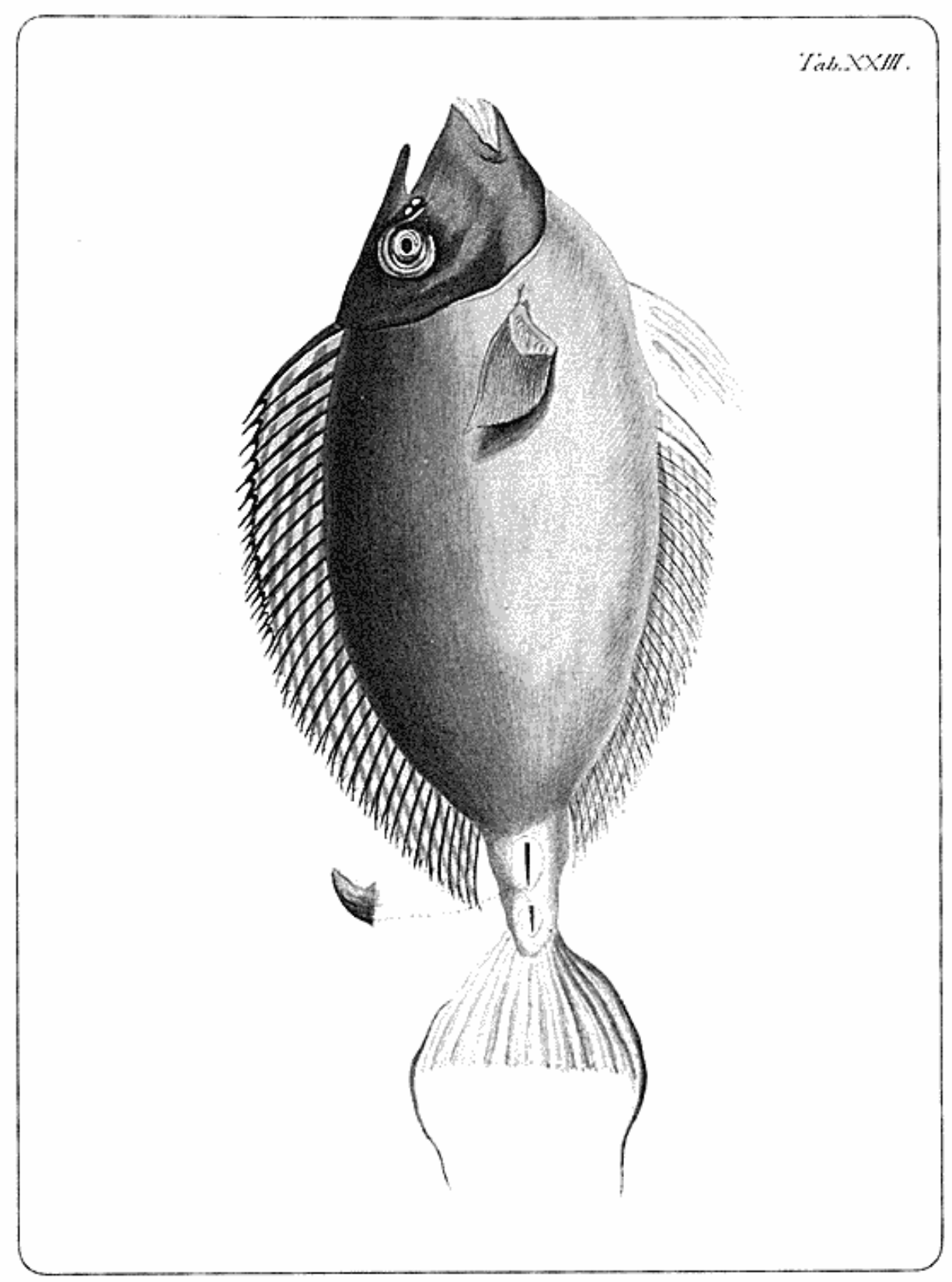

Icones rerum naturalium, 1776 , planche 23 .

Denne kirurgfisk, som har navnet Naso unicornis, gav Forsskål navnet Chaetodon unicomis. Lag marke til, at det andet navn, det vil sige artsnavnet, stadigvek bruges i den moderne systematik. Forsskål skrev; at den på arabisk hedder abu garn. Dette er et dialektnavn, da dens navn på klassisk arabisk ville blive transkriberet til abû qarn. Navnet kan oversattes til "behornet," hvilket Forsskall da heller ikke undlader at anføre i sin beskrivelse af fisken $i$ Descriptiones Animalium s. $6_{3} \mathrm{nr}$. 88 . Ifølge artikelforfatterens egne undersøgelser i det sydlige Sinai har fisken blandt lokale beduiner navnet „rahwa“ (Provençal 1997, s. 41 nr. 59), men blandt agyptere fra Nilområdet, som arbejder i turistindustrien på stedet, kan den hedde walyíd al-qarn, hvilket betyder énhornet. 
ikke var udviklet på dette tidspunkt, og dels at Forsskål i meget høj grad skrev til eget brug. Han regnede jo med, at han selv skulle skrive og redigere sine rapporter, når han kom hjem fra Den Arabiske Rejse. Desuden kan nogle af transskriptionerne vare svere at analysere sprogligt, hvis man ikke kender den dialekt, som de blev skrevet ned på. Heldigvis er der efterhånden givet en del gode beskrivelser af de forskellige berørte dialekter, således at det filologiske dybdearbejde med Forsskåls optegnelser bliver muligt. Ikke desto mindre kan vi kun beklage den manglende konsekvens i transskriptionerne. Det, som Forsskål især kunne være slem til, var, at han ikke skelnede mellem emfatiske $^{20}$ og almindelige konsonanter. Her lader Forsskål os ofte i stikken, og det er kun, hvis han samtidig har noteret navnet på dyret eller planten ned med arabiske bogstaver, at vi kan vide, hvilken type konsonanter der menes. Hvis ikke, må vi ty til andre kilder for at kunne finde dyre- og plantenavnenes rette udtale.

\section{Forsskåls samlinger i moderne arabisk leksikografisk arbejde}

I de klassiske tekster møder man ofte en række dyrebeskrivelser, som er så precise, at en artsidentifikation er mulig. Dog er det altid en stor fordel, hvis man kan møde navnet igen i en zoologisk tekst, i hvilken man træeffer en biologisk sikker artsidentitet. Her spiller Forsskåls $D e$ scriptiones Animalium en afgørende rolle, som de følgende eksempler viser:

1. I ægyptiske tekster fra $1300-0 g$ 1400-tallet beskrives en gåseart som "flodbredsgåsen": wizz "irâqî. Man kan ud fra beskrivelsen bestemme den som en Anser art. En af teksterne, nemlig den som findes hos al-Qalqashandî $\left(1355^{-1} 4^{18}\right)$, giver en beskrivelse, som er så nøjagtig, at arten kan bestemmes, nemlig som enten blisgås Anser albifrons eller som dværggås Anser erythropus. ." Imidlertid beskriver Forsskål en gås fra Egypten i Descriptiones Animalium, p. 3 nr. 6, som en blisgås og skriver at den hedder Ues araki på arabisk. Dette svarer til den æegytiske dialektale udtale af wizz 'irâqî. Dermed bekræftes, at blisgåsen har heddet wizz 'irâqî på klassisk arabisk.

2. I en biologisk og videnskabshistorisk særdeles vigtig liste med

${ }^{20}$ De såkaldt emfatiske konsonanter, $s$ d $!$ z og tildels q, har en sekundar artikulation, der klart adskiller dem fra de ikke-emfatiske konsonanter s d $\mathrm{z}$ og k, og som er betydningsberende; på arabisk skrives de da også med forskellige bogstaver.

${ }^{21}$ Provençal 1996 (note 1) s. 143. 
134/135 fuglenavne fra øen Tinnîs ${ }^{22}$ i Nilens delta, som senest stammer fra det 12. århundrede, står der et fuglenavn som sandsynligvis lyder som armîl eller armijal eller lignende. ${ }^{23}$ Forsskål skriver i Descriptiones Animalium, at i Alexandria kaldes rørdrummen Botaurus stellari $5^{24}$ for „Ariel“. Her er et af de navne, som Forsskål kun optegnede med latinske bogstaver. Imidlertid kan man ved kendskab til arabiske lydforhold regne ud, at den arabiske udtale må have varet ar'il, ari'al, arial eller lignende, hvilket på arabisk ligger grafisk tæt op ad armîlosv. Derfor er det sandsynligt, at fuglen, som står næunt i fuglelisten, er en rørdrum, især da de ekstensive rør- og papyrusskove, som da fandtes i denne lagune, passer denne art godt. ${ }^{25}$ Forsskål er mig bekendt den eneste person, som har noteret dette fuglenavn ned.

3. På klassisk arabisk er en af fæellesbetegnelserne for slanger tábân. Denne betegnelse bruges især om store slanger. Forsskål skriver i $D e$ scriptiones Animalium p. $14 \mathrm{nr}$. 7: ,Araberne kalder slangerne med en fælles betegnelse teecbân". På Sinai kalder beduinerne stadigvak slanger kollektivt for $\underline{\text { la }}$ bân. ${ }^{26}$ Hermed dokumenteres sammenhængen mellem klassisk arabisk og dialekterne.

4. Forsskåls betydning som kilde til arabiske dyrenavne er blevet anerkendt i Mellemøsten. Den irakiske zoolog Amîn Ma'lûf udgav i Kairo i 1932 et zoologisk og leksikalsk værk på arabisk om dyr og arabiske dyrenavne, ${ }^{27} \mathrm{i}$ hvilken han brugte Forsskål som kilde til belysning og forklaring af en hel del arabiske dyrenavne. I litteraturforklaringen til sit dyreleksikon skrev Ma'lûf om Forsskål: „(Forsskål) er en

${ }^{22}$ Tinnis er navnet på en $\emptyset$, som ligger i Manzalah-søen eller -lagunen i Nilens Delta. I løbet af den arabo-islamiske kulturs storhedstid fra det 9 . til det 13 . ârhundrede var Tinnis hjemsted for en meget rig by af samme navn, som dels fungerede som flådebase for de regyptiske herskere, dels var en sardeles vigtig eksporthavn for ægyptiske produkter. Sammen med den agyptiske havneby Damietta var byens tekstilindustri vidt berømt. I modsæetning til Damietta findes Tinnîs ikke mere. Byen blev beordret nedlagt både som flådebase og civil by i 1227 efter ordre fra den agyptiske sultan al-Kâmil, sandsynligvis som fø̆lge af et korsfarerangreb.

${ }^{23}$ Da man på arabisk ligesom på de fleste andre semitiske sprog kun skriver konsonanter og lange vokaler, vil det sige, at man i en uvokaliseret tekst, dvs. en tekst uden tegn til angivelse af de korte vokaler, altid er i tvivl om ordets egentlige udtale, medmindre man kender ordet i forvejen.

${ }^{24}$ Ardea stellaris hos Forsskål i Descriptiones Animalium (note 11), s. $8 \mathrm{nr} .10$.

${ }^{25}$ Provençal. P. 1995 (note 1).

26 Provençal 1997 (note 1 ) s. $37 \mathrm{mr} \cdot 17$.

${ }^{27}$ A. Ma'lûf Mu'jam al-Hayawân, An Arabic Zoological Dictionay, Cairo 1932. 
svensk videnskabsmand, som hørte til den kendte videnskabsmand Linnés disciple. Han blev født i $1736^{28}$ og døde af sygdom i Jerîm i Jemen i 1763 i sin ungdoms vår. Linné var hans lærer. Han blev anbefalet til den danske konge Frederik den Femte, som derpå sendte ham sammen med Niebuhr på en videnskabelig forskning[srejse] til Egypten og den Arabiske Halvø. De var fem videnskabsmænd, hvoraf ingen vendte tilbage til Danmark undtagen Niebuhr, som så publicerede sin kammerat Forsskåls bog (om dyr) efter hans død. Forsskåls bog er til vore dage det bedste, som er blevet skrevet om dyr i de arabiske lande. Freytag har overført mange [dyre] navne [til sit leksikon], ${ }^{99} \mathrm{og}$ ligeledes har al-Bustânî overført [navnemateriale] fra Forsskål til [sit arabiske leksikon] Muhît al-Muhît " ${ }^{\circ 0}$ (oversættelse fra arabisk af P. Provençal).

5. Mange af fiskene i Rødehavet bærer stadigvak på arabiske dialekter de navne, som Forsskål noterede ned. Dog varierer betegnelserne noget efter tid og sted. I tilfælde af dialektundersøgelser er Forsskål derfor en hovedreferencekilde, som kan hjælpe med til at forklare, hvordan de forskellige arabiske betegnelser varierer. ${ }^{31}$ Forsskåls samlinger af lokale fiskenavne er ydermere betydningsfulde, da det ser ud til, at Rødehavets fisk sprogligt set danner en enhed, som oven i købet ikke omtales i de klassiske arabiske varker. De kender faktisk ikke noget til disse fiskenavne fra Rødehavet, heller ikke de varker som er skrevet som eksplicitte leksikalske værker. ${ }^{32}$ Da de fleste af den klassiske arabiske litteraturs hovedværker blev skrevet i de store byer af veluddannede folk med en særdeles byorienteret tilgang til deres materialer, betyder det, at de i meget høj grad var afhængige af sekundære kilder. Det vil her sige enten af deres forgængeres værker eller af beretninger fra rejsende eller andre, som havde haft adgang til de ting, som disse forfattere skrev om. I denne henseende var Rødehavet efter alt at dømme et afsidesliggende sted, som der kun fandtes ringe viden om, også selv om den af Islam foreskrevne pilgrimsrejse til Mekka gjorde, at mange stiftede bekendtskab med denne geografiske region.

\footnotetext{
${ }^{2 s}$ Der er sandsynligvis tale om en trykfejl, da Forsskål blev født i $173^{2}$.

${ }^{29}$ Se note 42 .

${ }^{30}$ Butrus al-Bustânî, 1819-1883. Libanesisk litterat og leksikograf, som udgav en berømt arabisk ordbog ved navn Muḥ̂t al-Muhị̂. Butrus al-Bustânî spillede en stor rolle indenfor al-nahda, den litterare rennaissance som kendetegner moderne arabiske litteratur.

${ }^{31}$ Provençal 1997 (note 1).

${ }^{32}$ Provençal 1997 (note 1) s. 44.
} 
6. På Malta tales der en arabisk dialekt. Maltesisk er faktisk den eneste arabiske dialekt, som er blevet anerkendt som officielt sprog, idet man alle andre steder i den arabiske verden bruger klassisk arabisk. I Forsskåls Descriptiones Animalium står der på side XVIII - XIX en katalog over maltesiske fisk med 111 latinske artsnavne. ${ }^{33}$ Katalogens fulde titel er: Catalogus Piscium Melitensium a Medico Doctissimo Communicatus [Katalog over maltesiske fisk meddelt af en særdeles lærd læge]. Denne lege var sandsynligvis dr. Giorgio Giovan Battista Locano fra Senglea. ${ }^{34}$ Kataloget indeholder 69 mallesiske fiskenavne. Samme-

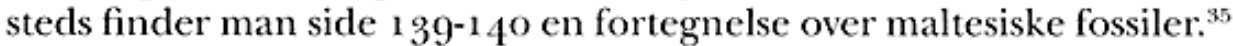
$\mathrm{Vi}$ har med andre ord de første moderne videnskabelige fortegnelser over fisk og fossiler fra Malta. ${ }^{36}$ I Forsskåls Flora Aegyptiaco-Arabica står der side XIII-XIV en „Lille Maltesisk Flora" ${ }^{\text {"37 }}$ med 87 latinske artsnavne. Der er dog ingen maltesiske plantenavne i denne liste. Det er imidlertid ikke den første videnskabelige liste over maltesiske plantearter. Den blev skrevet af den maltesiske læge Gian Francesco Buonamico i 1670,38 men blev ikke publiceret. Den første publicerede maltesiske flora blev udgivet i Rom ${ }^{39}$ i 1689 af den maltesiske læge Fillippo Cavallini. Denne flora indeholder 326 arter: ${ }^{40}$

7. Når det gælder planterne, spiller Forsskåls arabiske noter også en særdeles stor rolle. Forsskål er den første videnskabsmand i den vestlige tradition, som samlede en flora over Jemen, og han er den første, som fik nedfældet de jemenitiske plantenavne. Alene i Jemen fik Forskål indsamlet $75^{8}$ arabiske plantenavne drekkende 475 forskellige plantearter. ${ }^{41}$ Planterne står beskrevet i Flora Aegypliaco-Arabica, og li-

\footnotetext{
${ }^{33}$ Markeligt nok påbegyndes listen med to hvaler, nemlig „DELPHINUS ora " og "DELPHINUS delphis".

${ }^{34}$ G.Z. Maempel „The Arabian Voyage $1761-67$ and Malta: Forsskâl and his contribution to the study of Local Natural History," Reprints from Proceedings of History Week $1992 p p .35-76$, The Malta Historical Society, 1994, s. 61.

35 Testacea Fossilia Melitensia.

${ }^{36}$ Maempel (note 34 ) s. 65 .

37 Florula Melitensis.

${ }^{38}$ De Plantis quae in Melita et Gaulo observantur; Maempel (note 34 ) s. 55 note 34 .

${ }^{39}$ Pugillus meliteus seu omnium in insula Melita ejusque districtis enascentium perbrevis enarratio. Denne flora står skrevet i: Brevis enumeratio plantarum praesenti anno publico saptientae Romanae medicinalium simplicium professore ostensarum, et quae in Hortum Hyemalem redacte asservantur (s. 103-29) (Maempel (note 34 ) s. 55 note 34 ).

${ }^{40}$ Maempel (note 34 ) s. 55 note 34 .

${ }^{41}$ Schweinfurth (note 17) s. XVIII.
} 


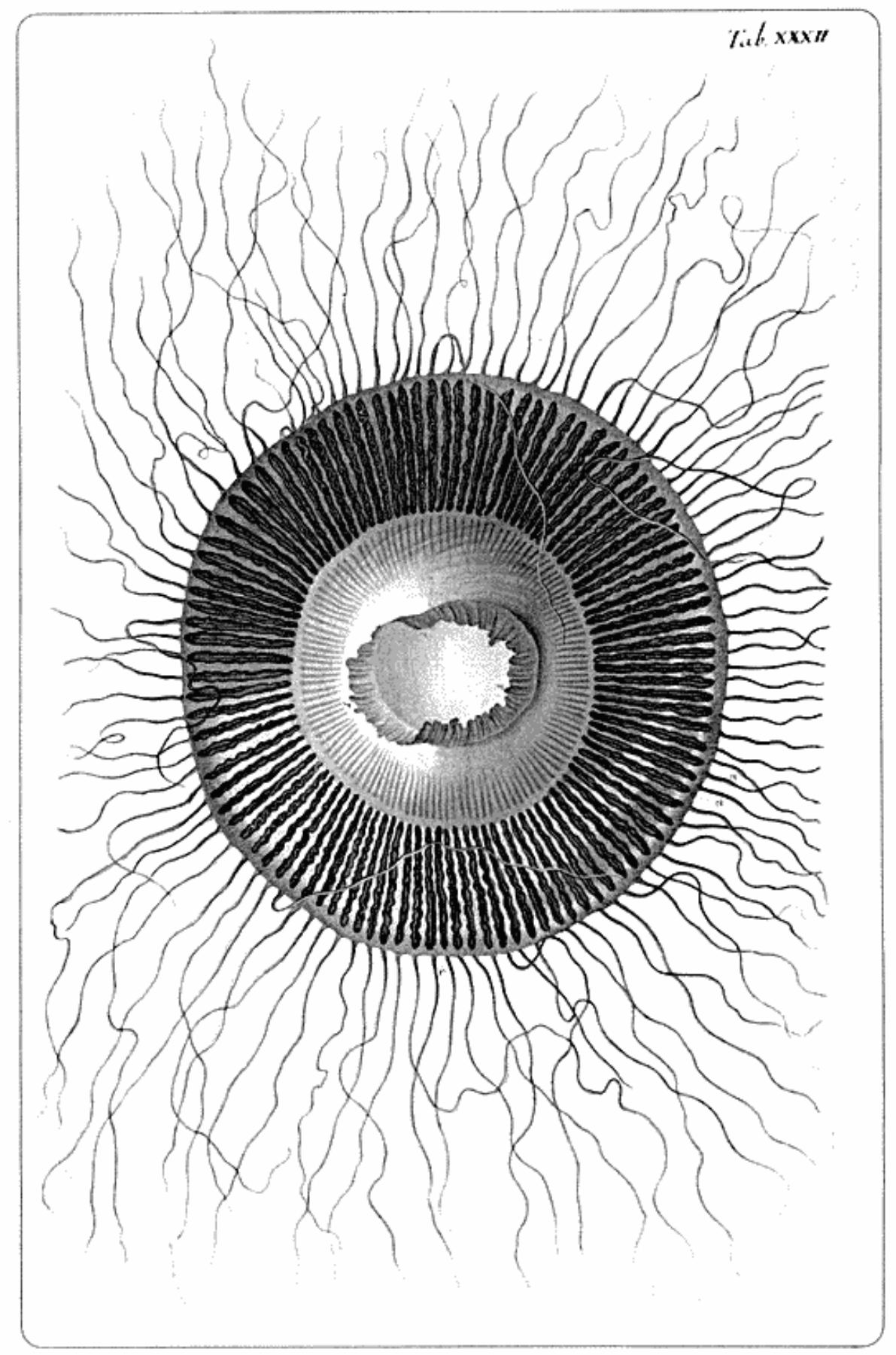

Denne gople, som Forsskal gav navnet Medusa equorea, berer nu navnet Aequorea forskilea. Denne gople fandtes ifølge Forsskal almindeligt i Atlanterhavet og i Middelhavet, men den findes i alle tropiske og varme tempererede have i verden. Forsskål skrev, at araberne kalder gopler ved fallesbetegnelsen kandíl el-báhr, hvilket ville vare qandil al-bahr i moderne transkription. Det betyder havlampe. En klassisk arabisk forfatter, Shams ad-Dîn Mubammad ad-Dimashqî $\left(125^{6-1327}\right)$, som skrev et kendt geografisk verk, beskriver en gople i Middelhavet, som lyser svagt i mørket - deraf navnet. Den gople, som ad-Dimashqî beskrev; er dog ikke samme art, som Aequorea forskilea. 
gesom i Descriptiones Animalium står de arabiske navne skrevne med både latinske og arabiske bogstaver, idet som allerede næunt de ca. $2 / 3$ af navnene i floraen også står skrevet med arabiske bogstaver.

Freytag, som udgav sit berømte arabisk-latinske leksikon i $1837^{42}$ brugte Forsskåls plantenavne i sit leksikon med kildeangivelse, men han gav som identitet den latinske artsbetegnelse som Forsskål selv gav ${ }^{43} \mathrm{og}$ som for mange arters vedkommende forlængst er foræeldet. ${ }^{44}$ Kazimirski har videreført nogle af disse plantenavne i sin arabisk-franske ordbog, ${ }^{45}$ dog uden kildeangivelse efter sin sadvane. Kazimirskis ordbog blev udgivet i 1860 , men han brugte stadigvak Forsskåls latinske artsnavne. Da denne ordbog fremdeles genoptrykkes og anvendes i vid udstrækning, vil det for en nuværende bruger sige, dels at nogle af de botaniske leksemer som behandles, er dialektale, og dels at de videnskabelige artsnavne, som angives, overhovedet ikke bruges mere. Som eksempel kan planten wuzar anføres. Den står angivet hos Kazimirski uden arabiske vokaltegn, hvilket er stik imod denne ordbogs sædvane, og den står angivet med det artsnavn Justicia paniculala, som Forsskål selv gav planten, men som ikke er gyldigt mere, da det nugæeldende artsnavn er Hypoestes forskalei. ${ }^{46}$ Desuden er plantenavnet wuzar et dialektnavn, som Forsskål noterede ned i overensstemmelse med den kongelige instruks. Kazimirski har simpelthen overtaget leksemet fra Freytag i den udformning, det har hos Freytag, og Freytag selv har ikke gjort andet end at overtage ordet, således som det står skrevet hos Forsskål i Flora Aegyptiaco-Arabica, p. 4. På samme måde har Freytag brugt Forsskåls dyrenavne og ligeledes angivet kilden. Kazimirski har igen i en del tilfalde brugt disse dyrenavne, som derfor $\mathrm{i}$ begge ordbøger står med det videnskabelige artsnavn, ${ }^{47}$ som Forsskål selv gav. ${ }^{48}$

${ }^{42}$ G.W. Freytag Lexicon arabico-latinum. Halle 1837 .

${ }^{43}$ Schweinfurth (note 17 ).

${ }^{44}$ En ajourført videnskabelig behandling af Forsskâls plantemateriale findes i F.N. Hepper \& I. Friis The Plants of Pehr Forskal's Flora Aegytiaco Arabica, Royal Botanic Gardens, Kew 1994.

45 A. B. Kazimirski Dictionnaire Arabe-Français, Paris 1860.

${ }^{46}$ Hepper \& Friis (note 44 ) s. 66.

${ }^{47}$ Det videnskabelige artsnavn er ikke altid angivet hos Kazimirski.

${ }^{18}$ For en videnskabelig behandling af nogle af disse artsnavne efter den moderne zoologiske nomenklatur se Provençal 1997 (note 1). 


\section{Konklusion}

De omtalte eksempler viser, at Forsskåls notation af arabiske navne på dyr er blevet brugt i vagtige leksikografiske værker, og at den stadigvak spiller en meget betydelig rolle for arbejdet med arabisk zoologisk og botanisk leksikografi og med den arabiske og islamiske kulturs videnskabshistorie. Der er endnu megen forskning at udføre, før vi kan opnå en fuld evaluering af Forsskåls bidrag til arabisk leksikografi, men hans notation af arabiske dyre-og plantenavne er en meget vigtig kilde til forståelsen af de særdeles indviklede forhold mellem klassisk arabisk og dialektalt arabisk, hvad angår dyre- og plantenavne; og for Rødehavsområdets vedkommende er den efter alt at dømme hovedkilden. Når det gælder kortlægningen af de indviklede forhold mellem navne- og artsidentiteten på arabisk, er det havet over enhver tvivl, at Forsskåls samlinger af dyre- og plantenavne udgør en særdeles væsentlig og betydelig reference, især når det drejer sig om sådanne organismer som fisk og hvirvelløse dyr, da de klassiske ordbøger lader os håbløst i stikken, hvad disse angår. På nuværende tidspunkt tør vi erklære, at Forsskål i vid udstrakning opfyldte de målsætninger, som står beskrevet i den kongelige instruks af 15 . december $1760 \$ 18$ :

„Med hensyn til alle de naturalier, som han nævner, skal han [Peter Forsskål] søge at tilføje de arabiske navne og at udtrykke disse både med arabiske og latinske bogstaver. Har én og samme ting forskellige navne $\mathrm{i}$ forskellige egne, så skal han ej heller undlade at gøre anmærkning om disse“. ${ }^{+9}$

Den videre målsæetning med disse noter var at skaffe grunddata til videre forskning inden for den semitiske filologi, jrevnfør det omtalte citat fra J.D. Michaëlis, og målet må siges at vaere opnået $i$ lyset af alt det arbejde, som er blevet udført af Forsskål selv, og den endnu større mængde arbejde, som står tilbage at udføre med Forsskåls notater og samlinger.

\footnotetext{
${ }^{49}$ Rasmussen (note 3 ) s. 70.
} 


\section{SUMMARY}

Phil.tppe Provencal: Peter Forsskall's contribution to Arabic lexicography

There are no parts of the history of science within the Classical Islamic Culture that are less investigated than those which treat of the history of biology and natural history. One of the main reasons for this is that the species identities behind an Arabic animal or plant name are mostly not known or at best very unprecise. In this respect field investigations where the local Arabic names are noted down and correlated on the spot with a given species are of highest interest. This demands a scientist who is trained both as a philologist and as a naturalist. Such a person was the Swedish naturalist and philologist of Semitic languages Peter Forsskål. He was the naturalist appointed to participate in the Danish scientific expedition to Egypt and Yemen $\left(1761-17^{6}\right)$ sent by king Frederik the Fifth of Denmark.

Forsskal had studied his two main disciplines under two of the most brilliant scientists of his century, namely the naturalist Carl von Linné (1707-1778) in Uppsala, Sweden, and the philologist Johann David Michaëlis $\left(1717^{-1} 79^{1}\right)$ in Göttingen, Germany. As one of the main objectives of the expedition was to find data which could elucidate obscure passages in the Bible, Forsskall was commissioned not only to investigate new species but to note down the Arabic names of plants and animals both with Arabic and with Latin letters. This he did scrupulously, even though many names are noted down only in one of the two alphabets.

Forsskal's notation thus represents a very substantial contribution to Arabic lexicography and the history of science in the Arabic civilisation. As his identifications and descriptions of species still stand as precise today, this precision gives a solid base for further philologic research using the name material which he noted down.

Seven examples of Forsskâl's contributions to the elucidation of Arabic lexicographic problems, or problems relating to the history of biology and natural history, are given. 